\title{
Lombardy, the Italian region most affected by Covid-19
}

Analysis of the socio-territorial aspects of the outbreak of the Seriana Valley

\section{Elisa Consolandi}

\section{CpenEdition}

\section{Journals}

Electronic version

URL: http://journals.openedition.org/rfst/863

DOI: $10.4000 /$ rfst.863

ISSN: 2492-3672

\section{Publisher}

Espaces et SOciétés (UMR 6590)

Electronic reference

Elisa Consolandi, "Lombardy, the Italian region most affected by Covid-19", Revue francophone sur la santé et les territoires [Online], Pandemic, crises and perspectives: territorial readings of Covid-19, Online since 19 February 2021, connection on 06 April 2021. URL: http://journals.openedition.org/rfst/ 863 ; DOI: https://doi.org/10.4000/rfst.863

This text was automatically generated on 6 April 2021.

\section{(i) $(2)$

La Revue francophone sur la santé et les territoires est mise à disposition selon les termes de la Licence Creative Commons Attribution - Pas d'Utilisation Commerciale - Partage dans les Mêmes Conditions 4.0 International. 


\title{
Lombardy, the Italian region most affected by Covid-19
}

\author{
Analysis of the socio-territorial aspects of the outbreak of the Seriana \\ Valley
}

Elisa Consolandi

1 Lombardy, as it is sadly known, is the Italian region which has been most affected by the SARS-CoV-2 virus. In fact, the first main sites of the pandemic in Italy were identified precisely in this area - specifically, in the provinces of Lodi, Crema and Bergamo (and, precisely, in the Seriana Valley). To better understand the intensity and severity of the outcomes of the infection in Lombardy and, more specifically, in the province of Bergamo, a group of researchers from the CST-Centro Studi sul Territorio of the University of Bergamo has conducted a study in order to understand whether the causes of this epidemic outcome can be connected with the social aspects of the territory. The aim of this analysis is therefore to understand whether the housing and functional complexity of the territory may have affected the severity with which the infection occurred in Lombardy, especially due to its rapid spread from the outbreak of propagation of the Seriana Valley.

2 From the first data relating to the pandemic main sites, it was hypothesized that the strong connection of the places determined the spread of the infection at first. At a later date, the spread of the virus could have occurred on the basis of the proximity as the most affected municipalities belong to the multicentric conurbation that characterizes the Lombardy region and, in general, the Po valley.

3 The methodology adopted during the analysis is strongly linked to the vision of the research, which assumes the contemporary way of inhabiting as mobile and urbanized. As regards the first aspect, commuting was investigated because it is considered as an indicator of the massive displacement of individuals between different territories and responsible of vast gatherings in public transports at particular times of the day. On the contrary, if we consider urbanity, both territorial diversity and density have been examined, since these characteristics are strong urban connotations. Indeed, Lombardy is characterized by a polycentric conurbation in which the urban polarities assume 
importance in times of pandemic, both for their population density, and therefore the potential possibility of spreading the disease by proximity, and because of the rhizomatic displacements that cause a diffusion by reticularity.

4 For this reason, we proceeded with the analysis of the composition of the population and the settlement typology of the examined territories. These characteristics have therefore been put in relation with the data of the pandemic spread in Lombardy, to understand why Covid-19 has affected this area so intensely. Therefore, a specific analysis of the Bergamo outbreak of the phenomenon was carried out in order to understand if the causes from which the contagion has started arise from the territorial organization in which it occurs or if they are rather the result of the way of inhabiting the territory.

5 Therefore, the social sense of the place was shown through the use of mapping, which having the merit of communicating the meaning of the territory on several levels and transmitting the complexity of the pandemic in progress - contributed to the understanding of the phenomenon, highlighting, at the same time, the territorial fragilities that arise from the analysis.

6 The case study intends to focus on the evolution of the infection and the socioterritorial complexity of the Seriana Valley, which is a valley situated along the course of the river Serio, across an area stretching to the northeast of the town of Bergamo. Specifically, the Seriana Valley has an unusual population distribution and different types of settlement: the lower part of the valley is characterized by a strongly urbanized continuum, which is configured as a peri-urban extension of Bergamo. This kind of urbanization is made up of rather big urban centers. In opposition, the upper valley is mainly composed of a set of medium-small municipalities. In addition, the conurbation located at the bottom of the valley is marked by the presence of about 50,000 residents and it is considered to be the gateway to the upper Seriana valley. These factors - together with the mobility that characterize the Seriana valley constitute the morphological and social complexity of the Bergamo outbreak and show that the severity of the phenomenon can be related to the characteristics of the territory in which the infection has spread most.

7 The results show that Lombardy and, in detail, some of its parts, are characterized by possessing all those elements identified as favoring the contagion, namely: the territorial morphology, the dense presence of industries and their network of commercial exchanges at national and international level, the intense daily school and work commuting, and, finally, the polycentric type of settlement that characterizes the Po Valley megalopolis and induces rhizomatic movements.

8 The morphological and social complexity of Lombardy - and, specifically, of the Seriana Valley "hotspot" - lead to the thesis that the gravity of the phenomenon is related to these characteristics of the territory. 


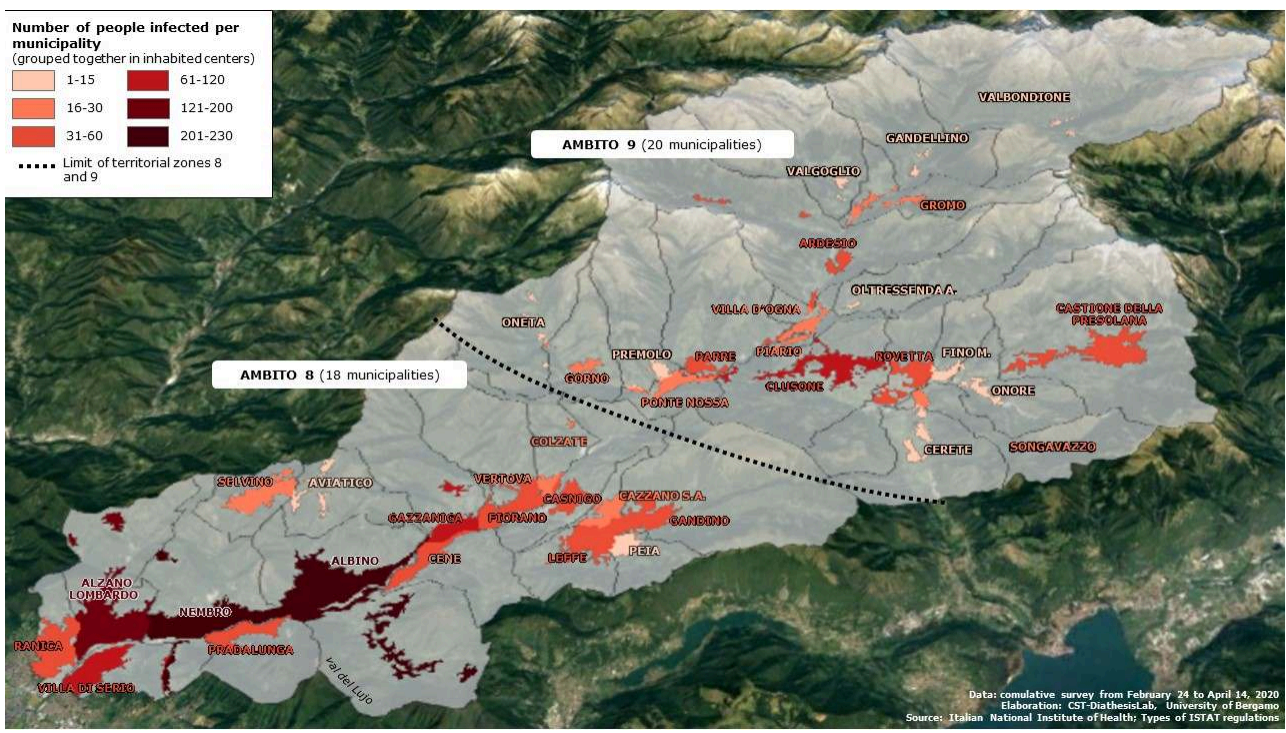

INDEX

Keywords: territorial analysis, reflective mapping, Covid-19

\section{AUTHOR}

\section{ELISA CONSOLANDI}

Doctorante à l'Université de Bergame 